\title{
Effectiveness of Advertising and Sales Promotion on Buying Decision of Smartphones in Kathmandu Valley
}

\author{
Nisha Sharma Adhikari ${ }^{I}$
}

\begin{abstract}
:
Advertising has the most prominent and vital impact on buying behavior of consumers. Smart phones have gained a lot of popularity in Nepal and are considered to be a great multimedia tool. With such growing demand of smartphones, the need for effective advertising has also been raised. This paper centers on the impact of advertising on the sales volume of Smartphones. This work will shed light on how advertising can really affect a consumer's buying decisions in a growing economy and how successful advertising can keep businesses going even in the midst of a tough competition. The entire data is collected by distributing structured questionnaire to the 150 respondents within Kathmandu valley. The outcome generated from descriptive statistic is that, most of the respondents own Samsung phone followed by iPhone and Online media is considered as the most effective adverting tool among other two. From the findings, we can also examine that there is insignificant relationship between gender and trust of information towards advertisement. Similarly, online, offline and electronic media have a insignificant association between gender, whereas influence through the advertisement of a brand has a significant association among age. Further the correlation analysis shows that there is a significant association among online, offline and electronic media.
\end{abstract}

Keywords: electronic media; brand name; social influence; descriptive analysis and operating system

\section{Introduction}

In this modern age of globalization and technology, an effective advertising tool is useful to influence consumer buying behavior on mobile phone sector in Nepal. Thus, it is important for practitioners and researchers to understand the pathway through which advertising influences consumer's selection. Different group of people have used different types of promotional activities of the products and services to attract consumers. However, these activities are used for a limited area

\footnotetext{
Ms. Adhikari is an MBA Graduate from Ace Institute of Management, affiliated to Pokhara University.

Corresponding Email: sharmanishaadhikari@gmail.com
} 
Adhikari: Effectiveness of Advertising and Sales Promotion ...

for promotion. But in this era of technology, advertisement has become significant way to promote products and services and is utilized for communication purpose. No company can become a market leader unless they invest lots of their budget in their promotional strategies (Hussainy, et al. 2008). Everyone is growing up in the society embedded in mass media like television, internet, radio, videos, bill boards, magazine, newspaper, social networking and other mediums. Marketers consider advertising as the best way to communicate to consumer and convince them about their product and service. It is renowned for its broader exposure and considered as long-lasting tool to set image on consumers' mind regarding any idea or product. (Abideen, farooq and latif, 2011). The foremost aim of advertising is to set an impact on buying behavior, furthermore, this impact about brand frequently strengthens or changes people's memories. Memories about the brand comprise of those associations that are interrelated to brand name in consumer mind. These brand cognitions manipulate consideration, valuation, and finally purchase (Romaniuk and Sharp, 2004). In Nepal, mobile phone industry has gained a lot of popularity i.e. the market size of smart phones has grown to 27.85 million against the total population of 26.49 million (according to Department of customs 2016) in which, advertisement plays an important role to achieve this reputation. The smartphone market is swamped with numerous global brands along with the emerging Indian and Chinese brands. Samsung, iPhone, HTC, LG, Sony Xperia, Colors, Micromax, Huawei, Xiaomi, Lava and Microsoft are some of the brands that have gained a prominent position in our local market. Each of these brands offers varieties of applications and features for people of all age groups. With global brands competing along with the Indian and Chinese ones, the price has come down significantly in the last few years. The availability of low end Smartphone devices with better features in the market is another major facet for the growing smart phones trend.

With all these numerous brands floating in the market, Nepalese people today have a wide variety of options to meet their needs of a Smartphone. Smartphone brands' war and promotional activities have heated the local market and all brands try to win their position. It is imperative for marketers to understand the important factors sought by consumers of different age groups, educational background, occupation and income level while buying Smartphone's.

Therefore, the basic objective of this research is to evaluate the effectiveness of advertising and sales promotion for attaining and retaining the market concentrating on smartphone business. Similarly, the objective is also to study the most influential factors for the sales promotion of smartphones in Nepal. Lastly, it 
will examine the most preferred brand of Smartphone. Through this study, these technology manufacturers and marketers can understand what factors affect consumer's preference of Smartphone and how they can market their Smartphone to tap into the Nepalese market.

The majority of the studies that have been conducted so far only focus on advertising types such as celebrity endorsement, consumer retention through TV advertising, brand loyalty of smartphones and so on. Unlike other studies, this paper examines the different types of media i.e., Online advertising, Offline advertising and Electronic advertising that one should focus on while promoting the smartphones. Hence, this paper gives a fair idea as to which media to follow for information to the right target audience. Also, different respondents in different age groups, occupation, income have different kinds of preferences.

The remaining sections are organized as follows: The second section follows with the review of literature and theoretical framework. Additionally, it sheds light on the research gaps. The third section presents the research methodologies that has applied while conducting the study. It highlights research design, sampling, sample size, nature and sources of data, validity and reliability test of data. Section four supports the report work with result and discussion. Section five provides the concluding remarks of the entire report.

\section{Review of Literatures}

The research aims at finding out the factors that majorly influence the buying decision of a customer while choosing a Smartphone. By reading the relevant literature, various factors have been found, based on the consumer choices about the Smartphone. The previous researches provide a range of variables which affect the purchase decision, combining several dominant variables, certain major factors can be drawn out. In the first quarter of 2012, Smartphone sales accounted for $34 \%$ of total mobile phone sales (Gartner.com, 2012). It is predicted that Smartphone sales will approach one billion units in 2016 (IDC.com, 2011).A study by (Magar, 2016) on factors affecting consumers purchase decision towards smartphones in Kathmandu valley, it is found that main reason for smart phone purchase is its features and the advertisement in the internet.Alshurideh (2014) has conducted a study keeping an objective to provide a new explanation for consumer retention from a behavioral perspective. This study has employed the Behavioral Perspective Model (BPM) to explain consumer behavior and predict retention based on the antecedents and consequences of learning contingencies in the mobile phone sector. It is found that marketing activities directly or indirectly influence consumer retention behavior by affecting consumer experience. Similarly, the study by 
(Arshad et al., 2014) has aimed to understand the context of effective advertising and its influence on consumer buying behavior and to find out how consumers are affected by emotional and environmental responses represented in advertisements. It has concluded that both the emotional as well as environmental responses in advertisements have great influence on consumer buying behavior and majority of people buy mobile phone sets after watching television ads. Gupta and Sheoran (2013) have made a study on "Consumer Behavior on Smartphone's: A Study on The Perceptions of Youth Population While Purchasing Smartphone's. It is found that majority of respondents are influenced by advertisements while the consumers are still influenced by the information provided by their peer groups on the quality, performance, style etc. Awasthi (2012). The results have showed that the main reason for smart phone purchase is its features. Internet retailers/ reviews/ technology websites are an important source of information to consumer. Mostly consumer wants to opt for different smartphone brands instead of looking for the same brand. The conclusion from this research is that the consumers are not brand loyalty in case of smartphone. According to Mei Mini and et al. (2012), the possible factors affecting the demand among young adult are product features, brand name, price, social influences. Similarly, (Ahmed and et al., 2012) conclude that; customers are highly motivated to purchase by celebrities that appear in advertisements but they also look for celebrity-product association. There are few studies which illustrated the impact of advertisements on behavior of consumers. Bolatito (2012) has analyzed how advertisement effectiveness play role in brand selection and how consumers give preference to a particular brand in telecommunication industry. Likewise, Spry and et al. (2011) have made a study on "Celebrity endorsement, brand credibility and brand quality". In conclusion, the study has empirically examined and confirmed the impact of endorser credibility on brand credibility and consumer-based brand equity. In advertisements, goods, services, ideas and organizations are promoted through television which is the main source to reach wide variety of consumers. Advertising from all mediums plays crucial role to influence people but in our society television is the main source to watch advertisements that persuade not only life cycle but also attitudes, behaviors and even culture of the country (Abideen, Farooq and Latif, 2011).

Most of the literature that has been presented so far, mainly sheds light on the various methods of advertising (i.e., impact of advertising on purchase decision, celebrity endorsement, emotional and behavioral advertising and lastly on brand loyalty) whereas this paper tries to give the fair idea on which type of media one should focus on while promoting their Smartphone brands. 


\section{The Methodology}

\subsection{The conceptual model}

A basic model is developed so that it serves as a foundation on which the entire research is based. In reference to various studies on effectiveness of advertising and sales promotion on buying behavior of smartphone, we have come across with the following model for the research.

Book of Awasthi (2012), "Consumer Buying Behavior towards Smartphones" has been considered as a key literature paper to study the effectiveness of advertising on sales of smartphone and also to study about the consumer motivation for buying a Smartphone.

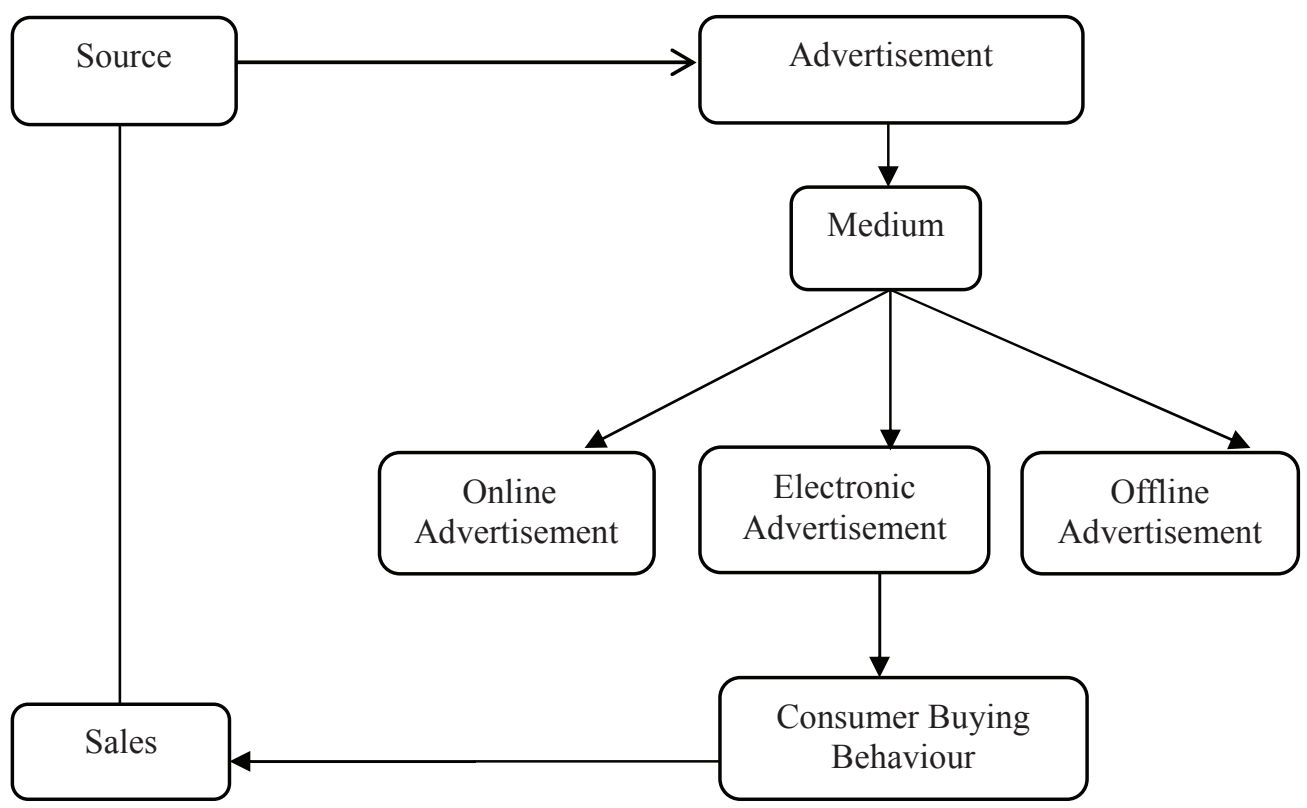

Figure 1. Conceptual framework

\subsection{Specification of variables}

Dependent Variable: In this research, the dependent variable is buying behavior of consumer towards the smartphone. The effect on respondent's buying behavior towards Smartphone than other normal cell phones has based on the various dependent variables. The factors that influence the Consumer Buying Behavior would include the different medium of advertisement and those are as follows: 
Adhikari: Effectiveness of Advertising and Sales Promotion ...

Online Advertisement: It refers to advertising and marketing efforts that use the Web and email to drive direct sales via electronic commerce, in addition to sales leads from Web sites or emails.

Electronic Advertisement: Electronic media are media that use electronics or electromechanical audience to access the content.

Offline Advertisement: It is any promotion or advertisement that is published and released outside the Internet.

Independent variables: The independent variable is the variable that is manipulated by the researcher. Here independent variables are gender, age, income and occupation. Gender: The research will look at how the gender of the respondents affects the buying Behavior of respondents towards Smartphone. Age: The age of the respondent is classified into different categories. They are below 25, $25-35,35-45$ and 45 and above. It is classified to study the differences in their preference and look at the difference among the eligible teens, respondent in their $20 \mathrm{~s}, 30 \mathrm{~s}, 40 \mathrm{~s}$ and $50 \mathrm{~s}$ age groups. Income: The income is grouped as below Rs. 20,000, 20,000-30,000, 30,000-40,000 and 40,000 and above. Occupation: The occupation is classified as businessperson, service holder, student, housewife, and others.

\subsection{The data}

The research design of this study is descriptive as well as analytical. This is the study of practical use of marketing and sales promotion tools and their effectiveness, so the appropriate research designs are followed according to the requirement of the study. The present study has its objective to analyze, examine and describe the application and effectiveness of marketing and sales promotion strategies and techniques.

The population of this study consists of people living inside Kathmandu Valley, which has more than a population of 2.5 million people. According to the data published by the Trade and Export Promotion Center (TEPC), Nepal imported 3.12 million units of mobile handsets worth Rs. 9.90 billion in FY 2013/14. Annually 1.8 million smart phones are sold in Nepal as said by Mobile Association of Nepal. Though specific data is not available on Smartphone users, Kathmandu valley has the vast majority of the Smartphone users being the economic hub of the country.

Since the population is very large and vague, it is not possible to incorporate each and every user in this research. Hence, the survey has used quota and convenience 
sampling method under non-probability sampling technique to determine the sample size. The quota is allocated for the sample of smart phones' consumers based on gender. Each gender is given minimum 75 samples to meet the statistical validity. Therefore, the survey has taken the sample size of 150 people representing the total population residing in Kathmandu Valley. They also vary according to the gender, age, occupation and monthly income level.

The research is conducted using quantitative as well as qualitative method. Quantitative data is collected with the help of questionnaire. The data collected from the questionnaire is analyzed using the mathematical tools and the result is presented in tables for clear understanding to the reader. The conclusion is drawn from the findings and from the analysis of the research and recommendation is made accordingly. Likewise, secondary data is acquired through journals, books, websites etc. for literature review.

To assure the validity of the research, the selected theories and questionnaire have been extracted from other scholars who studied in the relevant field and have concrete and convincing conclusion supported by papers.

Different tools and techniques have been used to present and analyze the existing marketing, advertising and sales system. Such tools consist of SPSS 16.0 software in order to collect the data. The collected data are logically and systematically entered using SPSS software and analysis done as per the requirement of study. Descriptive as well as Inferential analysis are used for analyzing the data. Central tendency, frequency table, Chart, Graph and Chi-square are used for descriptive analysis. Whereas Hypothesis testing, Chi-square test, F-test, ANOVA and other testing are done for internal analysis.

\section{Result and Discussion}

\subsection{Demographic profiles of the respondent}

The details about the respondents captured in this survey included, gender, age groups, income level and professions limited to Kathmandu valley. 


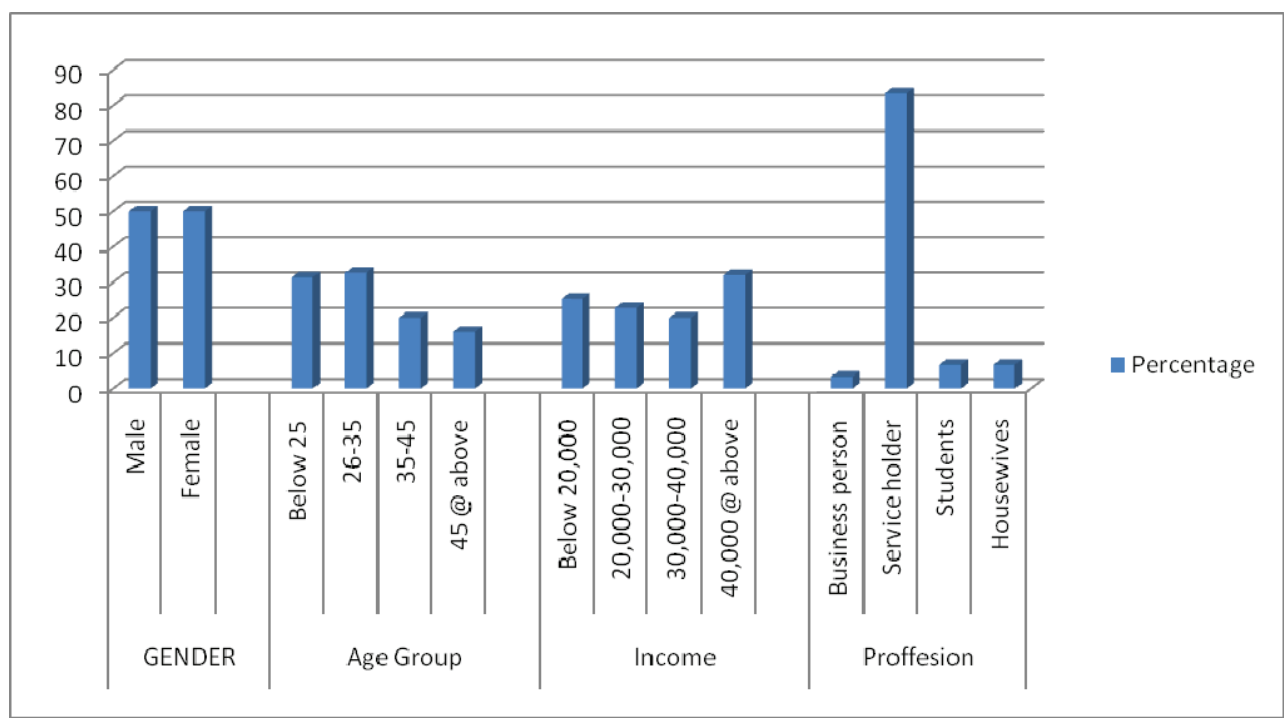

Figure 2. Demographic profiles of the respondents

\subsection{Descriptive statistics}

Among 150 respondents, the highest percentage i.e. 22.67\% owns Samsung phone followed by Apple iPhone with $20 \%$ whereas the lowest brand owned by respondents is Colors by $2 \%$. The majority of respondents with $68.7 \%$ consider websites as the most influential factor for making buying decision of smartphone, followed by $60.7 \%$ considering Social marketing, then by $52 \%$ considering from Newspaper whereas by $41.3 \%$ follows T.V and $32 \%$ follows promotional materials. However, the least impact is from radio where only $18.7 \%$ respondents follow while making a buying decision of smartphone. It is found that among other brands, Samsung by $50 \%$ is considered as the most recalled advertisement followed by iPhone i.e. $24.67 \%$ whereas the least is Gionee by $2 \%$. Similarly, it is examined that Brand by $26 \%$ is considered as the most influential source of information for buying decision followed by advertisement by $15.33 \%$. Lastly, the majority of respondents choose Online media (56\%)as the most authoritative factor for making buying decision of smartphone followed by Electronic media with $22.7 \%$ and the least Offline media by $21.3 \%$ respectively. 


\subsection{Cross tabulation analysis}

The table 1 shows the cross tabulation between gender and their overall trust for advertisement. As illustrated in above table, out of 42 respondents 30 are males and 12 are females who agree that they trust the information provided in the advertisement.

Table 1: Cross Tabulation of gender and trust of information towards an advertisement

\begin{tabular}{|c|c|c|c|c|c|c|}
\hline \multirow[b]{2}{*}{ Gender } & \multicolumn{5}{|c|}{ Do you trust the information provided in the advertisement } & \multirow[b]{2}{*}{ Total } \\
\hline & $\begin{array}{l}\text { Strongly } \\
\text { Agree }\end{array}$ & Agree & Neutral & Disagree & $\begin{array}{l}\text { Strongly } \\
\text { Disagree }\end{array}$ & \\
\hline \multirow{2}{*}{ Male } & 30 & 28 & 3 & 13 & 1 & 75 \\
\hline & $40 \%$ & $37.33 \%$ & $4 \%$ & $17.33 \%$ & $1.33 \%$ & 100 \\
\hline \multirow{2}{*}{ Female } & 17 & 42 & 5 & 3 & 13 & 75 \\
\hline & $15.99 \%$ & $56 \%$ & $6.67 \%$ & $4 \%$ & $17.33 \%$ & 100 \\
\hline \multirow{2}{*}{ Total } & 42 & 70 & 8 & 16 & 14 & 150 \\
\hline & $25.66 \%$ & $46.67 \%$ & $5.33 \%$ & $10.67 \%$ & $9.33 \%$ & 100 \\
\hline
\end{tabular}

Out of them who are neutral, 28 are males and the remaining 42 are females. Similarly, among total respondents 13 are males and 3 are females who disagree with the same. However, the count of female are large i.e. 13 who strongly disagree with the statement. This finding indicates that with the high percentage, respondents have a trust with advertisement

\subsection{One sample T-test analysis}

Here, the analysis covers all the statistical analysis made to verify the hypothesis and ascertain the significance of purchase intention of smartphone and gender.

Table 2: Analysis of electronic media affecting purchase decision between genders

\begin{tabular}{|l|l|l|l|l|l|l|l|}
\hline Source of Media & $\begin{array}{c}\text { Source of } \\
\text { Advertising }\end{array}$ & Gender & $\mathbf{n}$ & Mean & $\begin{array}{c}\text { Std. } \\
\text { Deviation }\end{array}$ & $\begin{array}{c}\text { t- } \\
\text { value }\end{array}$ & $\begin{array}{c}\text { p- } \\
\text { value }\end{array}$ \\
\hline \multirow{3}{*}{ Electronic Media } & \multirow{2}{*}{ TV } & Male & 75 & 0.36 & 0.48 & \multirow{2}{*}{-1.325} & 0.75 \\
\cline { 2 - 7 } & \multirow{2}{*}{ Radio } & Female & 75 & 0.47 & 0.5 & \\
\cline { 3 - 8 } & Male & 75 & 0.15 & 0.36 & \multirow{2}{*}{-1.256} & 0.51 \\
\cline { 2 - 6 } & Female & 75 & 0.23 & 0.42 & \\
\hline
\end{tabular}

The table shown above illustrates that there is no significant relationship between gender and Electronic media as a factor affecting the purchase decision of smartphone. 
Adhikari: Effectiveness of Advertising and Sales Promotion ...

Table 3: Analysis of offline media affecting purchase decision between genders

\begin{tabular}{|c|c|c|c|c|c|c|c|}
\hline $\begin{array}{c}\text { Source of } \\
\text { Media }\end{array}$ & Source of Advertising & Gender & $\mathbf{N}$ & Mean & $\begin{array}{c}\text { Std. } \\
\text { Deviation }\end{array}$ & t-value & p-value \\
\hline \multirow{6}{*}{ Offline Media } & \multirow{2}{*}{ Newspaper } & Male & 75 & 0.53 & 0.5 & \multirow{2}{*}{0.325} & \multirow{2}{*}{0.589} \\
\hline & & Female & 75 & 0.51 & 0.5 & & \\
\hline & \multirow{2}{*}{ Promotional activities } & Male & 75 & 0.29 & 0.46 & \multirow{2}{*}{-0.697} & \multirow{2}{*}{0.62} \\
\hline & & Female & 75 & 0.35 & 0.48 & & \\
\hline & \multirow{2}{*}{ Magazines } & Male & 75 & 0.47 & 0.5 & \multirow{2}{*}{0.654} & \multirow{2}{*}{0.49} \\
\hline & & Female & 75 & 0.41 & 0.5 & & \\
\hline
\end{tabular}

The table above shows that there is no significant relationship between gender and Offline media as a factor affecting the purchase decision of smartphone.

Table 4: Analysis of online media affecting purchase decision between genders

\begin{tabular}{|c|c|c|c|c|c|c|c|}
\hline $\begin{array}{c}\text { Source of } \\
\text { Media }\end{array}$ & $\begin{array}{c}\text { Source of } \\
\text { Advertising }\end{array}$ & Gender & $\mathbf{N}$ & Mean & $\begin{array}{c}\text { Std. } \\
\text { Deviation }\end{array}$ & t-value & p-value \\
\hline \multirow{4}{*}{ Online Media } & \multirow{2}{*}{$\begin{array}{ll}\text { Social } & \text { Media } \\
\text { Marketing } & \\
\end{array}$} & Male & 75 & 0.59 & 0.5 & \multirow{2}{*}{-0.499} & \multirow{2}{*}{0.19} \\
\hline & & Female & 75 & 0.63 & 0.49 & & \\
\hline & \multirow{2}{*}{ Websites } & Male & 75 & 0.71 & 0.46 & \multirow{2}{*}{0.525} & \multirow{2}{*}{0.21} \\
\hline & & Female & 75 & 0.67 & 0.47 & & \\
\hline
\end{tabular}

Table 4 shows that there is no significant relationship between gender and Online media as a factor affecting the purchase decision of smart phone.

\subsection{Correlation analysis}

In this section, we will discuss correlation analysis, which is used to quantify the association between two continuous variables. A positive correlation indicates the extent to which those variables increase or decrease in parallel; a negative correlation indicates the extent to which one variable increases as the other decreases. 
Table 5: Correlation analysis

\begin{tabular}{|l|l|l|l|}
\hline & $\begin{array}{l}\text { I think Electronic } \\
\text { media is the best } \\
\text { option for making } \\
\text { buying decision of } \\
\text { smartphone }\end{array}$ & $\begin{array}{l}\text { I think offline media } \\
\text { is thest option for } \\
\text { making buying } \\
\text { decision of } \\
\text { smartphone }\end{array}$ & $\begin{array}{l}\text { I think online media } \\
\text { is best option for } \\
\text { making } \\
\text { decision } \\
\text { smartphone }\end{array}$ \\
\hline $\begin{array}{l}\text { I think Electronic } \\
\text { media is the best } \\
\text { option for making } \\
\text { buying decision of } \\
\text { smart phone }\end{array}$ & 1.00 & 0.34 & 0.17 \\
\hline $\begin{array}{l}\text { I think offline media } \\
\text { is the best option for } \\
\text { making buying } \\
\text { decision of smart } \\
\text { phone }\end{array}$ & & $(0.00)$ & $(0.04)$ \\
\hline $\begin{array}{l}\text { I think online media is } \\
\text { the best option for } \\
\text { making buying } \\
\text { decision of smart } \\
\text { phone }\end{array}$ & & & -0.10 \\
\hline
\end{tabular}

The correlation between "I think offline media is the best option for making buying decision of smart phone" and "I think electronic media is the best option for making buying decision of smart phone" is 0.34 , which is less than 0.05 . Therefore, there is a significant association between two statements.

Similarly, the correlation between "I think online media is the best option for making buying decision of smart phone" and "I think electronic media is the best option for making buying decision of smart phone" is 0.17 , which is less than 0.05 . Therefore, there is a significant association between two statements.

Finally, the correlation between "I think online media is the best option for making buying decision of smart phone" and "I think offline media is the best option for making buying decision of smart phone" is 0.10 , and its p-value $(0.24)>0.05$ which is less than 0.05 . Therefore, there is insignificant association between two statements.

\subsection{One way analysis of variance}

Table 6 shows the analysis on the impact of online media on the buying decision among various age groups. 
Adhikari: Effectiveness of Advertising and Sales Promotion ...

Table 6: Analysis of getting influence by brand advertisement among various age groups

\begin{tabular}{|c|c|c|c|c|c|c|}
\hline Factor & Age & $\mathbf{N}$ & Mean & $\begin{array}{c}\text { Std. } \\
\text { Deviation }\end{array}$ & $\mathbf{F}$ & Sig. \\
\hline \multirow{5}{*}{$\begin{array}{l}\text { Influence through the } \\
\text { Advertisement of a } \\
\text { brand }\end{array}$} & Below 25 & 47 & 2.47 & 0.72 & \multirow{5}{*}{7.86} & \multirow{5}{*}{0.00} \\
\hline & $26-35$ & 49 & 2.71 & 1.1 & & \\
\hline & $35-45$ & 30 & 2.03 & 1.13 & & \\
\hline & $45 \&$ above & 24 & 1.67 & 0.76 & & \\
\hline & Total & 150 & 2.33 & 1.01 & & \\
\hline
\end{tabular}

Since the $\mathrm{P}$-value $=0.00$ is equal to significance value 0.05 , which means there is a significant relationship between age and impact of online media on the buying decision among various age groups.

Table 7: Analysis on impact of advertisement on buying decision among various age groups

\begin{tabular}{|c|c|c|c|c|c|c|}
\hline Factor & Age & $\mathbf{N}$ & Mean & $\begin{array}{l}\text { Std. } \\
\text { Deviation }\end{array}$ & $\mathbf{F}$ & Sig. \\
\hline \multirow{5}{*}{$\begin{array}{l}\text { Advertising affects } \\
\text { consumer Buying } \\
\text { Behavior }\end{array}$} & Below 25 & 47 & 2.38 & 0.8 & \multirow{5}{*}{0.16} & \multirow{5}{*}{0.92} \\
\hline & $26-35$ & 49 & 2.35 & 0.48 & & \\
\hline & $35-45$ & 30 & 2.3 & 0.53 & & \\
\hline & $45 \&$ above & 24 & 2.29 & 0.62 & & \\
\hline & Total & 150 & 2.34 & 0.62 & & \\
\hline
\end{tabular}

Table 7 shows the analysis on the impact of advertisement on the buying decision among various age groups. Since the P-value $=0.92$ is greater than the significance value 0.05 , which means there is insignificant relationship between age and impact of various schemes offers among various age groups.

Table 8: Analysis on the impact of online media on the buying decision among various age groups

\begin{tabular}{|l|l|l|l|l|l|l|}
\hline Factor & Age & N & Mean & Std. Deviation & F & Sig. \\
\hline \multirow{2}{*}{$\begin{array}{l}\text { I think online media is the } \\
\text { best option for making } \\
\text { buying }\end{array}$} & Below 25 & 47 & 1.96 & 0.75 & & \\
\cline { 2 - 6 } Smartphone decisionof & $26-35$ & 49 & 1.57 & 0.76 & \\
\cline { 2 - 6 } & $35-45$ & 30 & 1.53 & 0.86 & \multirow{3}{*}{0.04} \\
\cline { 2 - 5 } & $45 \&$ above & 24 & 1.88 & 0.9 & \\
\cline { 2 - 5 } & Total & 150 & 1.73 & 0.82 & \\
\hline
\end{tabular}

Table 8 shows the analysis on the impact of online media on the buying decision among various age groups. Since the P-value $=0.04$ is less than the significance 
value 0.05 , which means there is a significant relationship between age and impact of online media on the buying decision among various age groups.

Similarly, table 9 shows the analysis on the impact of offline media on the buying decision among various age groups.

Table 9: Analysis on the impact of offline media on the buying decision among various age groups

\begin{tabular}{|l|l|l|l|l|l|l|}
\hline \multirow{2}{*}{ Factor } & Age & N & Mean & $\begin{array}{l}\text { Std. } \\
\text { Deviation }\end{array}$ & F & \multirow{2}{*}{ Sig. } \\
\hline \multirow{2}{*}{$\begin{array}{l}\text { I think offline media is the } \\
\text { best option for making } \\
\text { buying decision of } \\
\text { Smartphone }\end{array}$} & Below 25 & 47 & 2.51 & 0.59 & & \\
\cline { 2 - 6 } & $26-35$ & 49 & 3.06 & 1.25 & \\
\cline { 2 - 6 } & $35-45$ & 30 & 2.23 & 1.25 & \multirow{3}{*}{0.01} \\
\cline { 2 - 6 } & $45 \&$ above & 24 & 2.88 & 1.33 & \\
\cline { 2 - 5 } & Total & 150 & 2.69 & 1.13 & \\
\hline
\end{tabular}

Since the $\mathrm{P}$-value $=0.01$ is less than the significance value 0.05 , which means there is a significant relationship between age and impact of offline media on the buying decision among various age groups.

Table 10 also shows the analysis on the impact of buying decision due to the festive offers among various age groups.

Table 4.10: Analysis on impact of electronic media on buying decision among various age groups

\begin{tabular}{|c|c|c|c|c|c|c|}
\hline Factor & Age & $\mathbf{N}$ & Mean & $\begin{array}{l}\text { Std. } \\
\text { Deviation }\end{array}$ & $\mathbf{F}$ & Sig. \\
\hline \multirow{5}{*}{$\begin{array}{l}\text { I think Electronic media is } \\
\text { the best option for making } \\
\text { buying decision of } \\
\text { Smartphone }\end{array}$} & Below 25 & 45 & 2.82 & 0.86 & \multirow{5}{*}{6.32} & \multirow{5}{*}{0.00} \\
\hline & $26-35$ & 49 & 2.24 & 0.83 & & \\
\hline & $35-45$ & 30 & 2 & 1.02 & & \\
\hline & $45 \&$ above & 24 & 2.21 & 0.83 & & \\
\hline & Total & 148 & 2.36 & 0.93 & & \\
\hline
\end{tabular}

Since the $\mathrm{P}$-value $=0.00$ is equal to the significance value 0.05 , which means there is a significant relationship between age and impact of electronic media on buying decision among various age groups.

\section{Concluding Remarks}

The objective of the research is to find out the underlying factors that play a major role to determine the brands while customers purchase Smartphone in Kathmandu. The research has identified many factors that are deemed as selection criteria of 
Smartphone. Not necessarily all the variables influence a consumer in the same way and to the same extent. The variables under investigation in this study include selection of media i.e., electronic media, online media and offline media. This study was conducted with the objective to identify the most preferred brand of Smartphone and to examine the effects of advertisement and promotional offers on Consumer's Buying Behavior towards a Smartphone and finally, to analyze the most preferred media for advertisement of Smartphone. The study reveals that the majority of respondents currently own Samsung brand $(22.67 \%)$ followed by Apple iPhone and Gionee brand respectively.

In order to create an impact in the mind of the consumers, one has to use different Medias i.e., Electronic media (TV, Radio), Offline media (Magazines, Promotional Materials, Hoarding boards) and Online media (Internet, Websites and Social Media Marketing).To talk about the most preferred media, the results show that the consumers have got the information regarding the smartphones mostly through Online media(internet) i.e. (54\%) followed by TV and others respectively. Hence, internet seems to be most preferred media among others for respondents to make a buying decision of smartphone. The paper also concludes that among the genders, females are the one who have more impact on the buying decision of Smartphone due to advertisement than the male.

Although this study has attempted to find the effectiveness of advertisement on the sales of smart phones in Kathmandu valley, there are some perceivable research limitations with regards to the convenience sampling as the number of respondents is restricted to only Kathmandu valley. Hence, it may not be a perfect representation of the population. Futhermore, there is chance of response errors due to many factors such as misinterpretation, hesitation, unawareness and so on among the respondents.

In a nutshell, the study shows that advertisement is a necessity and has to be taken into consideration as it plays a major role in the success of any brand. The paper also implies that the smartphone manufactures, and distributors need to work on building a unique brand position in the minds of the customers with the help of different advertisement tools. Moreover, there are few theories from 2010-2013 that concludes; features of smartphones rather than advertisement plays a major role in the sales of smartphones, which contradicts from my findings. 


\section{References}

Akim, M. (2011). Predicting consumers' behavioral intentions with perception of brandpersonality: A study in cell phone markets. International Journal of Business and Management, Vol. 6(6), 234-242

Agterhuis, D.J. (2012). Effects of apps on consumer behavior of smartphones and telecommunication providers: features fatigue vs. mass customization. Unpublished Doctoral Dissertaton, Eindhoven University of Technology.

Ahmed, A., Mir, F.A.,\& Farooq,O.(2012). Effect of celebrity endorsement on customers' buying behavior; a perspective from pakistan. Interdisciplianry Journal of Contemporary Research in Business, Vol. 4(5), 584-592.

Al-azzawi, M., Anthony, M. (2012). Students brand preferences between Apple and Samsung Smartphone. Unpublished Doctoral Dissertstion, Malardalen University.

Awasthi, V. (2012). Study of consumer buying behavior towards smart phone.Unpublished Master Thesis, Gaur HariSinghania Institute of Management \& Research.

Coelho, D.C., Meneses, R.F.C., \& Moreira, M.R. (2013). Factors influencing purchase intention of private label products: The case of smartphones. Exploring Services Science, Vol. 143(1), 313-321.

Gupta R. and Sheoran B. (2013). Consumer behaviour on smartphone's: A study on the perceptions of youth population while purchasing smartphone's. international journal of research in mangement \& social science, Vol. 1(1), 61-73.

Hornsby, G.D. (2011). Attributes affecting consumer choice. Unpublished master thesis, Oklahoma State University.

Hamka, F. (2012). Smartphone's customer segmentation and targeting: Defining market segment for different type of mobile service providers. Unpublished M.Sc. Thesis, Delhi University of technology.

Jung,Y. (2013). What Smartphone is to me: understanding user values in using smatphones. Information Systems Journal, Vol. 923(6), 21-27.

Karjaluoto, H., Karvonen, J., Kesti M., Koivumaki Y., Manninen M., Pakola J., \& Ristola, A. (2005). Factors affecting consumer choice of mobile phones: Two Studies from Finland. Journal of Euro Marketing, Vol. 14(3), 59-82. 
184 Adhikari: Effectiveness of Advertising and Sales Promotion ...

Mathur, A., Moschis, G.P., \& Lee, E., (2001). A study of changes in brand prefernces. Asia pacific Advances in Consumer Research, Vol. 4(1), 133-139.

Osamn, M.A., Talib A.Z., Zainal A.S., Shiang- yen T. \& Alwai A.S., (2012). A study of the trend of smartphone and its usage behavior in malaysia. International Journal on New Computer Architechtures and their Applications, Vol. 2(1), 274-285.

Pughazhendi, A., \& Ravindran, D.S. (2012). A study on the influence of using celebrity endorsements on consumer buying behavior in Tamil Naidu, India. Journal of research in International Business Mangement, Vol 2(4), 89-96

Sahin., A., Zehir, C., \& Kitapci, H. (2011). The effects of brand expeeriences, trust and satisfaction on building brand loyalty; an empirical research on global brands. Procedia- Social and Behavioral Sciences, Vol. 24(3), 1288-1301.

Spry, A., Pappu, R., \& Cornwell, T.B. (2011). Celebrity endoresement, brand credibility and brand quity. European Jouranl of Marketing, Vol. 45(6), 882909.

Suki, N.M. (2013). Student's dependence on smart phones: The influence of social needs, social influences and convenience. Campus- Wide Information Systems, Vol. 30(2), 124-134.

Travagli, F. (2013). Smartphone Buying Behavior: The Chasm between Early and Late Adopters. Unpublished Masters Thesis, Copenhagen Business School.

Verkasalo, H., Lopez- Nicolas, C., Molina- Castillo, F.J., \& Bouwan, H. (2010). Analysis of users and non-users of smartphone applications. Telematics and Informatics, Vol. 27(3), 242-255. 